\title{
School-Linked Services: Practice, Policy, and Constructing Sustainable Collaboration
}

\author{
Twyla Salm
}

University of Regina

\begin{abstract}
In Saskatchewan, many of the provincial practices and policies addressing health and social issues including, poverty and social exclusion in multi-service schools are informed by an integrated services policy called School ${ }^{\text {PLUS }}$. This study explores how School ${ }^{\text {PLUS }}$ discourse has shaped and continues to produce the collaborative integrated services landscape and impact wider social strategies even though it is no longer considered government policy. Three factors are suggested as reasons for School ${ }^{\text {PLUS, }}$ s decline. First, School ${ }^{\text {PLUS }}$ practice became edu-centric and marginalized other professions in blatant and subtle ways. Second, the level of collaborative competencies needed to perform collaboration is often underestimated-for School ${ }^{\text {PLUS }}$ too much might have been expected too fast-and finally, there was a daunting complexity factor at the macro level. Data was collected by analysing academic publications and public documents, including government newsletters and the provincial teacher's newspaper. A practice policy paradox is revealed, suggesting that the concept of School ${ }^{\text {PLUS }}$ emerged organically from the vernacular of practice and continues to produce, and be reproduced, in this domain regardless of the current, official interprofessional policy.
\end{abstract}

Keywords: multi-service schools; policy; integrated services 


\section{School-Linked Services: Practice, Policy, and Constructing Sustainable Collaboration}

In Canada, integrated school-linked services is a provincial responsibility, creating a cadre of practices and policies across the nation aimed at supporting collaboration across human sectors to improve student learning, health and well-being. In Saskatchewan, many of the provincial practices and policies addressing health and social issues, including poverty and social exclusion in multi-service schools, are informed by an integrated services policy called School ${ }^{\text {PLUS }}$ (Tymchak, 2001). This policy stemmed from a comprehensive document entitled, School ${ }^{\text {PLUS }}$ : A Vision for Children and Youth, which provided direction for new institutional designs in the human service sector in this province. More than a catalyst for collaboration, School ${ }^{\text {PLUS }}$ offered a strategy to ensure better learning outcomes and a healthier and more just society and Saskatchewan was described as a province "ripe for change" (Tymchak, 2001, p. 7). Even though more than a decade has passed since the School ${ }^{\text {PLUS }}$ inception, and the enthusiasm for school-linked services has waxed and waned over the years, this policy direction continues to be salient. Nationally, it has been taken up in other provinces in various forms, most directly in Nova Scotia as SchoolsPlus (Province of Nova Scotia, 2014) and in Manitoba as the Community Schools Partnership Initiative (Province of Manitoba, 2014). Internationally, School ${ }^{\text {PLUS }}$ has been recognized as a promising practice (Dyson, 2011).

According to Dyson (2011), School ${ }^{\text {PLUS }}$ has a unique perspective in the way it describes school-linked services as a means to build flourishing and sustainable communities rather than merely a response to social maladies. Yet, and perhaps not surprisingly, a change of this magnitude has been fraught with difficulty. As Lawson (2003) suggests, effective school-linked services does not tinker at the edge of reform; it necessitates complex changes to organizations, systems, and professional identities. Policy-makers are often clear about the desired outcomes of school-linked services, but there is far less evidence of how these policies might actualize in strategies that support meaningful change (Hulme, Cracknell, \& Owens, 2009). Contributing to the global but embryonic dialogue analyzing the contributing and inhibiting factors related to school-linked service policy development, this paper explores the how the concept of School ${ }^{\text {PLUS }}$ has been constructed in public discourse since its inception.

Data was collected by analysing academic publications, public documents, including government newsletters and the provincial teacher's newspaper. Subsequently, the discussion explores how School ${ }^{\text {PLUS }}$ discourse has shaped and continues to produce the collaborative integrated services landscape and impact wider social strategies. Specifically, a practice policy paradox is revealed, suggesting that the concept of School ${ }^{\text {PLUS }}$ emerged organically from the vernacular of practice and continues to produce, and be reproduced, in this domain regardless of the current, official interprofessional, school-linked service policy. This discussion is significant to other jurisdictions because the complicating factors both accelerating and decelerating School $^{\text {PLUS }}$ are applicable to other sites where similar school-linked services are also developing. Although there is some useful analysis of policy development related to school-linked services conducted in the United Kingdom (Raffoet al., 2009), there is a paucity of research from a Canadian perspective, despite the veracious appetite for the idea of school-linked service practice in this country. 


\section{Overview of School-Linked Services}

The concept of integrated services dates back over 100 years (Tyack, 1992), but at the turn of the millennium there was a resurgence of interest in integrated services across the globe. Evidence of this revitalization was marked by the Full Services School Movement in both the United States (Dryfoos, 2002) and Australia (James \& St. Leger, 2003) and by the Every Child Matters agenda in the United Kingdom (HM Treasury, 2003). Similarly, interprofessional collaboration and Full Service Schools literature is often couched in broader discourses related to expanded school improvement models (Anderson-Butcher et al., 2010; Furrer, Magnuson, \& Suggs, 2012; D'Angelo, Rich, \& Kwiatt, 2013) and educational reform (Ainscow, Dyson, Goldrick, \& West, 2012). The common thread in all of these movements acknowledges that "educational outcomes in particular are shaped by a range of non-education factors-ranging from interactions within particular families to peer groups and neighbourhood effects to poverty and social class" (Dyson, 2011, p. 178). The complexity of the issues in this context necessitates partnerships and

[collaboration] is evident when interdependent, autonomous stakeholders with their respective competency domains mobilize resources, and both harmonize and synchronize their operations to solve shared problems, meet common needs, capitalize on important opportunities, and obtain prized benefits. (Lawson, 2004, p.227)

Over time, the call for and the development of school-linked and/or interprofessional collaboration between schools and other services has been sustained (Anning, Cottrell, Frost, Green, \& Robinson, 2010; Edwards, Daniels, Gallagher, Leadbetter \& Warmington, 2009; Crane \& Livock, 2012). However, the complexity actualizing collaboration is difficult when there is often a lack of organizational structure, strategy for collaboration, and possibly even dominance and antagonism between professionals (Anderson-Butcher et al., 2010). Saskatchewan's version of school-linked services reflects this international movement that acknowledges that in order to improve the conditions for children and youth, schools must be aligned with wider social strategies (Dyson, 2011). However, unlike other full-service models, which generally called for schools as the coordination point for enhanced networks of health and social services (Forbes \& Watson, 2012) School ${ }^{\text {PLUS }}$ was designed with a wider focus for change. Tymchak (2001) states that School ${ }^{\text {PLUS }}$ called for "nothing more and nothing less than a forging of a new society" (p. 5).

\section{Data Collection}

A literature review (Patton, 2002) was conducted in two academic databases, ERIC and

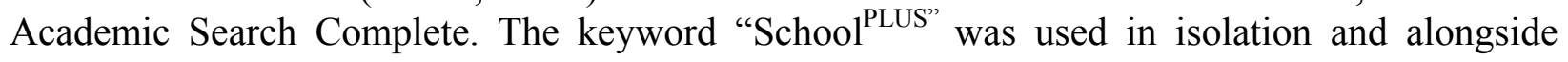
Tymchak (2001) as author and "full-service community schools" as a second key phrase. These same key words were also used in an online grey literature search, with a particular focus on searching the provincial government website (White et al., 2013). Finally, an online and manual search of the term School ${ }^{\text {PLUS }}$ in the Saskatchewan Bulletin archives was also conducted. The Saskatchewan Bulletin is a tabloid newspaper published 10 times per school year by the Saskatchewan Teachers' Federation (STF), the professional organization representing over 12,000 teachers in publically funded schools in Saskatchewan. The circulation is approximately 23,000 per issue (STF, 2014). Even though this type of tabloid might be considered less credible, grey literature makes a substantial contribution to education research and has an impact on learning and awareness of educational research and practices (White et al., 2013). 
In this study, the Bulletin was selected as one of the primary sources because it captures significant events as well as serendipitous comments of educators and government officials addressing educational issues. Documents referencing School ${ }^{\text {PLUS }}$ from 2001 - 2014 were collected in a purposeful, non-sampling matter and analyzed using context analysis-specifically documents as commentary (Miller \& Alvarado, 2005). This approach to document analysis is helpful to interpret social phenomena, such as how the concept of School ${ }^{\text {PLUS }}$ was constructed in various documents. It also provides researchers with a framework to use documents "as commentary to provide insight into individual and collective actions, intentions, and meanings, organizational dynamics, and institutional structures, in short, to interpret the social reality indicated in the documents" (Miller \& Alvarado, 2005, p. 351).

\section{School $^{\text {PLUS }}$ Beginnings}

Saskatchewan's version of school-linked services and interprofessional collaboration was coined

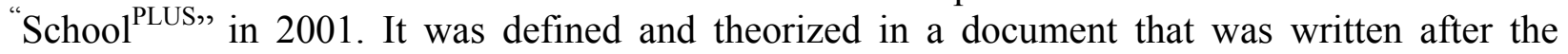
Minister of Education's Task Force conducted a comprehensive study and engaged in extensive public dialogue $(1999$ - 2001). The guiding question for the public dialogue was to examine the changing role of the school. The task force was composed of 12 individuals with varying professional and personal experiences and was chaired by Dr. Michael Tymchak, then Dean of the Faculty of Education at the University of Regina. Based on three years of extensive public dialogue, the Task Force (Tymchak, 2001) concluded that schools today have two functions:

1. To educate children and youth — nurturing the development of the whole child, intellectually, socially, spiritually, emotionally and physically.

2. To support service delivery - serving as centres at the community level for the delivery of appropriate social, health, recreation, culture, justice, and other services for children and their families.

In the Task Force document, School ${ }^{\text {PLUS }}$ underscored the integrated and collaborative purpose of schooling and, for the first time in provincial public policy, acknowledged the role of schools as part of a service delivery network. Further, Tymchak (2001) proposed that School ${ }^{\text {PLUS }}$ must be unique, creating a systemic structure, not only subsuming but also moving beyond the scope of Community Schooling and/or Full Service Community Schools (Dryfoos, 1994). In that way, the vision for School ${ }^{\text {PLUS }}$ was to be more than school reform: It was to be educational reform with a systemic and vigorous strategy to advance integrated human services. While most Full Service Schools focus on offering additional services to students and their families, the scope of School ${ }^{\text {PLUS }}$ was described in broader terms with the intent to provide the capacity to align the work of schools with wider social strategies. As Tymchak (2001) states,

School $^{\text {PLUS }}$ will be a completely new organizational environment for meeting the needs of children and youth, not just as we know it with more added on. It will be a matrix organization that draws all of its resources from existing government and non-government agencies and coordinates and integrates those resources in relation to the needs of children and youth. (p. 13)

In addition to the new organizational environment, the report suggested new roles and partnerships for government, administrators, teachers, universities, students, and teachers. Beyond interprofessional collaboration, there was a wide range of recommendations ranging 
from improving technology to enhancing early childhood education. In that way, the report had both depth and breadth in terms of changes to policy and practices. In an effort to demonstrate broad government support, the report was acknowledged by each of the human service sectors, including Education, Health, Social Services, Justice, Aboriginal Affairs, Culture Youth and Recreation, Post-Secondary Education and Skills Training, as a new social institution and adopted as provincial policy (Ministry of Education, 2002). Each government sector contributed to a response document entitled Securing Saskatchewan's Future (Ministry of Education, 2002) and this collective effort was designed to affirm the widespread consensus and commitment to this type of reform. Specific goals, plans of action, and changes to government structures were outlined in this document. The first government actions included the establishment of three committee structures to oversee the implementation:

1. Saskatchewan Council on Children and Youth: senior representatives from the human service sector and community leaders.

2. Strengthening Educational Capacity Forum: senior representatives from the teachers union (STF), the school board association, the school division directors, the universities, and Aboriginal and youth leaders.

3. Interdepartmental Children and Family Services Integration Forum: senior officials from the government's human service departments who are tasked to "oversee a systematic and vigorous strategy to advance integrated human services" and to among a list of additional items, "resolve systemic and structural issues such as [coterminous] boundaries" (p. 8).

During 2002, when the implementation stage emerged, School ${ }^{\text {PLUS }}$ was considered a provincial strategy led by the Ministry of Education. Over the last 13 years, the work from the three committees noted above has been dismissed, actualized, and adapted in particular ways. The areas related to school-linked services and interprofessional collaboration are of particular significance to this paper. An examination of provincial government documents from $2002-$ 2005 reveals many references to School ${ }^{\text {PLS }}$, which were produced primarily in the Ministry of Education. The type of documents ranged from glossy promotional material distributed to schools and education stakeholders to comprehensive guidebooks aimed at using School ${ }^{\text {PLUS }}$ philosophy to "mobilize forces within a community" setting (Ministry of Education, 2004, p. 3). Typically, the newsletters reported a mix of anecdotal exemplars of school-based service delivery initiatives and reports of how specific government decisions responded to particular recommendations in the Role of the Schools report. Examples of action included a description of the increase in pre-kindergarten placements and summaries of specific connections the Ministry was making with other ministries, including Health, Culture, Youth and Recreation and Justice (Ministry of Education, 2003).

In these early years, the government message was consistent in that Saskatchewan was "creating a new social institution" (Ministry of Education, 2003, p. 1). Although some of the claims were pedantic - "all school are centres of community, open and welcoming" (p. 2) - the message that sectors needed to collaborate to be more effective and that resources needed to be realigned for improved integrated services ignited new hope for more widespread systemic change. 
The majority of the grey literature was developed in these early stages of School ${ }^{\text {PLUS }}$ implementation. Typically, the grey literature demonstrated the intent to engage all levels of the Education sector, from government officials to teachers in School ${ }^{\text {PLUS }}$ initiatives. Coordinated by the Ministry of Education, a research consortium published Destination School ${ }^{\text {PLUS }}-A$ Leadership Guide for School ${ }^{\text {PLUS }}$ Environments and established three working committees, inviting both meso and micro level involvement. These three working committees were established were to advance School ${ }^{\text {PLUS }}$ leadership in the areas of (a) Preservice, (b) In-Service and (c) Community Youth Leadership. The Preservice Committee conducted a survey to identify

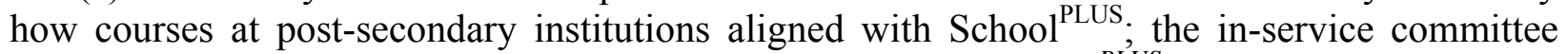
produced a resource called Many Roads Taken: Stories of School ${ }^{\text {PLUS }}$, a document describing examples of School ${ }^{\text {PLUS }}$ in practice; and finally, the Community and Youth Leadership committee developed a resource directory, containing existing programs that support youth leadership.

Beyond government initiatives, School ${ }^{\text {PLUS }}$ was also being taken up in the academy. Carr-Stewart (2003) suggested that as a provincial initiative, School ${ }^{\text {PLUS }}$ offered a vision for Aboriginal communities and a way to bridge the divide between provincially and federally supported First Nation schools. She states:

School ${ }^{\text {PLUS }}$ goes beyond striving for harmony and association between two groups who have been historically cocooned within their spheres. It is purposefully designed to provide quality educational opportunities for all residents in the province while fostering community identity and supporting community involvement in decision making. It is about making concrete educational changes and charting new education directions for all Saskatchewan residents. (Carr-Stewart, 2003, p. 231)

Additionally, School ${ }^{\text {PLUS }}$ has been theorized through an integral development theory as a framework to advance holistic leadership change (Regnier, 2012). Notably, as the concept of School $^{\text {PLUS }}$ evolved in all of these different forums, it was given shape by public and academic discourse and, reciprocally, it gave shape to established practices that were already percolating.

\section{School $^{\text {PLUs }}$ : The Thwarting Discourse Begins}

The interprofessional partnerships that were reported by the Ministry through various documents did not often challenge or champion new structural or policy changes. In fact, in the School ${ }^{\text {PLUS }}$ At a Glance Newsletter, the Ministry of Education (2003) highlighted in-school programs such as fitness programs that have existed for many years as evidence of School ${ }^{\text {PLUS }}$. One exception came from a senior Ministry of Education Director, who stated:

School $^{\text {PLUS }}$ holds great promise but the work ahead is challenging and complex. We need to make a long-term commitment to creating communities and schools that will meet the wellbeing and learning needs of all. (Ministry of Education, 2003, p. 3)

He continued by emphasizing the need for a "systemic and vigorous strategy" (p. 3) to enhance integrated human services. Despite his call for systemic change, ironically, the discourse of systemic changes was all but entirely lost in these types of reports by 2004. 
Not only was the systemic change agenda thwarted, but also School ${ }^{\text {PLUS }}$ was described as nothing new. A government newsletter widely disseminated throughout the province heralded that "School ${ }^{\text {PLUS }}$ is Happenin"!" and featured a plethora of anecdotal school-based stories, including one from the Centre of Excellence for Youth Engagement. This organization claimed that they have "been enormously successful in stressing the fact that School ${ }^{\mathrm{PLUS}}$ [was] not a new idea" (Ministry of Education, 2004, Winter, p. 1). And further,

Though there is an overwhelming lack of understanding among people in this and others sectors as to what School ${ }^{\text {PLUS }}$ is and how it can be operationalized, there are many programs, initiatives, and partnerships already happening in this province which are concrete examples of the School ${ }^{\text {PLUS }}$ philosophy. (Ministry of Education, 2004, Winter, p. 1)

The report ended with an anecdotal report of a school that imagined School ${ }^{\text {PLUS }}$ as a collaborative approach to educate parents on how to read what was considered a complex report card. Therefore, in only three years, School ${ }^{\text {PLUS }}$ discourse had shifted from changing a society to a nifty way to connect with parents through revised report cards.

Aligning School ${ }^{\text {PLUS }}$ with such mundane changes may have suggested that School ${ }^{\text {PLUS }}$ was near its demise. However, other activities that fostered continued discussion about the possibilities for a new social institution continued to emerge. During this time, the University of Regina hosted a School ${ }^{\text {PLUS }}$ Congress and the Ministry of Education sponsored a School ${ }^{\text {PLUS }}$ Shared Leadership Institute. While enthusiastic and well-meaning, these events were grounded with a predominantly edu-centric agenda, spurred by the presence of and leadership from primarily professionals whose main interest was directly related to Education. Where were all our partners in educational reform? By 2005, the flurry of initial School ${ }^{\text {PLUS }}$ government document development had waned, even in the Education sector, and by 2006, in a briefing to the Minister, the Saskatchewan Teachers Federation (STF) asked, "What has happened to School $^{\text {PLUS }}$ as the vision guiding our education system?" (Nielsen, April 26, 2006, p. 4) Prompted by discouraged teachers, they continue,

Understandably, teachers are discouraged from the educational landscape to be replaced by an emphasis on accountability mechanisms rooted in bureaucratic needs rather than the real needs of students and their teachers. (Nielsen, April 26, 2006, p. 4)

Throughout 2006, the Bulletin covered what they described as the demise of School ${ }^{\text {PLUS }}$ (Nielsen, Nov. 22, 2006) and one article stated that schools were already "doing a lot of what was proposed in School ${ }^{\text {PLUS }}$ anyway, well before it became formalized as a program by the government" (Nielsen, April 26, 2006, p. 1). Only a few months later, however, the Bulletin reported a summary of the activities related to the three round tables, acknowledging that realizing School ${ }^{\text {PLUS }}$ had been challenging, but the journey was still underway (Pillay, Jan. 24, 2007).

Contradictory messages abounded in 2007. Over the next six months, concern that School $^{\text {PLUS }}$ was disappearing was evidenced in these sentiments expressed in the Bulletin, "There have been numerous updates but the name $\left[\mathrm{School}^{\mathrm{PLUS}}\right]$ has all but been forgotten in the lexicon of public education policy" (Nielsen, June 13, 2007, p. 1). Yet, at the same time, the Bulletin reported that the Deputy Minister insisted, in her address to the Federation, that School ${ }^{\text {PLUS }}$ was 
"alive and working" (Nielsen, June 13, 2007, p. 1). One year later, in 2008, a new Deputy Minister repeated the performance and stated that School $^{\text {PLUS }}$ was intact. In an open forum, educators repeatedly asked the Minister of Education about his commitment to School ${ }^{\text {PLUS }}$ and he replied that he was determined to revitalize the all but moribund School ${ }^{\text {PLUS }}$ philosophy. Notably, he blamed other ministries for a lack of financial commitment (Nielsen, June 11, 2008). In a response to a question of whether School ${ }^{\text {PLUS }}$ was still alive, he responded in the affirmative and assured the crowd that School ${ }^{\text {PLUS }}$ was still a government priority. Arguably, there was widespread skepticism that the concept of School ${ }^{\text {PLUS }}$, at least as a provincial policy, had established itself beyond the Education sector boundaries.

There was evidence, however, that the concept of School ${ }^{\text {PLUS }}$ was still very much on the minds of educators. There are multiple examples of how the term School ${ }^{\text {PLUS }}$ spontaneously emerged as part of a teacher's regular discourse as they described their programs in the context of a School $^{\text {PLUS }}$ environment. For example, in an article not focused on School ${ }^{\text {PLUS }}$, a principal candidly explained the paediatric services model new to his school as a School ${ }^{\text {PLUS }}$ idea (Nielsen, June 11, 2008). Similarly, another principal described his school's Wellness and Education Centre as actualizing School ${ }^{\text {PLUS }}$ (Nielsen, Dec. 17, 2008). Whether the official policy was dead or alive seems debatable but the concept of School ${ }^{\text {PLUS }}$ had certainly taken root in practice and in the local vernacular.

\section{School $^{\text {PLUS }}$ : Later and Lingering Developments}

In April 2009, the government declared that there would be an increase in funding for the integrated services model and the STF expressed their satisfaction in this overture (Nielsen, April, 2009). There was a definite rekindling of School ${ }^{\text {PLUS }}$ interest as reported in the 2009 Bulletins. There were substantial examples of educators explaining their intersectoral partnership endeavors in the context of School ${ }^{\text {PLUS }}$ (Feb. 18, 2009). The Bulletin also provided substantial press to the "Caring Across Professions Conference" that highlighted the work of integrated school services and inteprofessional collaboration across the province. Notably, the conference hosted a panel of key senior government and community stakeholders who articulated their commitment to School ${ }^{\text {PLUS }}$, and as the Deputy Minister of Education stated, "a significant key priority [for government]" (Nielsen, June 17, 2009).

The concept of School ${ }^{\text {PLUS }}$ was mentioned incidentally in three articles over the next few months. Early in the new year, School ${ }^{\text {PLUS }}$ was associated with a collaborative judo-based learning program for youth, (Nielsen, January 20b, 2010) described by a professor in relation to student assessment (Nielsen, Jan. 20a, 2010) and identified by a school division as an inspiration for a new school council structure (Nielsen, June 16b, 2010). In the same issue, the president of the STF lamented that School ${ }^{\text {PLUS }}$ had the vision to be a "powerful catalyst for change but was never implemented to the extent that it needed to be" (Nielsen, June 16a, 2010, p. 3). By November, a senior medical officer reported that School ${ }^{\text {PLUS }}$ had "failed" (Nielsen, Nov. 10, 2010 , p. 3). At this point, the government had long since stopped publishing School ${ }^{\text {PLUS }}$ newsletters and adding information to the School $^{\text {PLUS }}$ web page. School ${ }^{\text {PLUS }}$ as a policy at a provincial level appeared to be, indeed, moribund. At the same time, however, a comprehensive story covered how a school division and a local intersectoral committee build partnerships to improve health and learning for children. A superintendent said, "It is actually School ${ }^{\text {PLUS }}$ working. Many people think School ${ }^{\text {PLUS }}$ is dead but it is alive and well here. It might not be called by that name... but it is certainly interorganizational collaboration... and it is working well 
(Nielsen, Jan. 19, 2011). At this point, the gap between how educators talked about School ${ }^{\text {PLUS }}$ practice and how School ${ }^{\text {PLUS }}$ policy was actualized seemed to have widened.

While references to School ${ }^{\text {PLUS }}$ continued to diminish in public documents through 2011, there was marked frustration from the STF that School ${ }^{\text {PLU }}$ had been "unrealized" (Nielsen, June 15, 2011) and even when the Minister announced an integrated model with six different ministries contributing, the STF president dismissed it as another empty promise (Nielsen, April 11, 2011). Additionally, in 2012, the School ${ }^{\text {PLUS }}$ web page on the Ministry of Education website was removed and no new School ${ }^{\mathrm{PLUS}}$ documents were available. If this move signaled the end of School ${ }^{\text {PLUS }}$ as a policy, it would not stop the concept of School ${ }^{\text {PLUS }}$ as a practice. The term School ${ }^{\text {PLUS }}$ continued to emerge in the speeches and descriptions of collaborative and innovative programs. There were four references to School ${ }^{\text {PLUS }}$ in the Bulletin in 2012. The first reference is in an interview with a principal who described School ${ }^{\text {PLUS }}$ as "stalled but laudable" (Nielsen, Febuary15, 2012, p. 3). The second and third references were remarks from politicians who continue to positively reference School ${ }^{\text {PLUS }}$ in their addresses to teachers (Nielsen, Oct. 17, 2012; Nov, 14, 2012) and the final reference was from an interview with the Chief Medical Officer who called for a concerted effort for intersectoral partnerships, "evoking a School ${ }^{\text {PLUS }}$ vision" (Nielsen, Dec. 12, 2012, p. 3). More than 10 years after its inception and almost 2 years since its removal from the website, there continued to be three more references to School ${ }^{\text {PLUS }}$ in 2013 in the Bulletin. One reference came from a principal, who in describing his school, said "this is School ${ }^{\text {PLUS }}$ at its grassroots and I would say you wouldn't see a better overall example of this in Western Canada" (Nielsen, Feb. 13, 2013, p. 4). Provincial Premier Brad Wall referenced School ${ }^{\text {PLUS }}$ in his address to teachers, stating that "many teachers have told him [that School ${ }^{\text {PLUS }}$ ] had considerable merit but was never properly resourced (Nielsen, June 12, 2013, p. 1). Similarly, in 2014 Deputy Minister Florizone "acknowledged the moribund School $^{\text {PLUS }}$ philosophy" (Nielsen, Jan. 14, 2014, p. 1). The concept of School ${ }^{\text {PLUS }}$ received significant acknowledgement from politicians for a reportedly waning idea.

Over the last several years, the Bulletin and other government documents have provided an interesting chronicle of the how the discourses of School ${ }^{\text {PLUS }}$ reveal its development and decline-sometimes even within the same year. Even though there are many contradictory messages about the state of School ${ }^{\text {PLUS }}$, the concept has survived in the discussions of educators and speeches of politicians. Why has School ${ }^{\text {PLUS }}$ experienced such a tumultuous existence? The next section discusses factors that may have contributed to the complexity of inter-sectoral collaboration, pivotal to the School ${ }^{\text {PLUS }}$ vision.

\section{School $^{\text {PLUS }}$ : The Complicating Factors}

The original policy document (School ${ }^{\text {PLUS }}$ a Vision for Children and Youth, 2001) provided 96 recommendations, specific suggestions for changes to organizational structures, a proposed budget, and a call for a cultural change. Arguably, many of the specific recommendations have been addressed; however, producing a cultural change is a rather tall order. School ${ }^{\text {PLUS }}$ was constructed in a similar way to the Full Service Extended Schools (FSES) in England. Like FSES, School ${ }^{\text {PLUS }}$ was "loosely specified at the government level" (Dyson \& Todd, 2010, p. 126), had an array of interpretations that resulted in an eclectic mix of activities (Salm, 2008), and resulted in old initiatives that were relabelled to be part of the School ${ }^{\text {PLUS }}$ approach. Before School $^{\text {PLUS }}$ had a chance to grow roots, it drew criticism that schools had been doing School ${ }^{\text {PLUS }}$ all along and the government was not doing much at all. There appears to be three major factors 
that shaped the "dark side" of School ${ }^{\text {PLUS }}$. First, School ${ }^{\text {PLUS }}$ practice became edu-centric and tended to marginalize other professions in blatant and subtle ways. Second, the level of collaborative competencies needed to perform collaboration was often underestimated-for School $^{\text {PLUS }}$, too much might have been expected too fast - and finally, there was a daunting complexity factor at the macro level.

\section{Edu-centric}

There has been a tendency for schools to be understood as the central hub for integrated services, serving children and youth. Even by its name, School ${ }^{\text {PLUS }}$ exudes the Education sector's central role in the quest for greater collaboration among professions and sectors. Certainly, for school-age children, schools are often the epicenter of collaborative efforts; however, for genuine collaborations to be effective, the work itself cannot be edu-centric. Cummings, Todd, and Dyson's (2007) study determined that educators were more inclined to understand communities as a resource for Full Service Community schools, rather than Full Service Community schools as a resource for communities. In their study, when professionals understood schools as a resource for communities, they were more likely to involve families and community members in authentic problem solving and decision making. Notably, educators with an extreme schooloriented understanding of schools, focused entirely on academic achievement, disregarding potential community support or the inclusion of other services. It is reasonable to query whether the prevailing School ${ }^{\text {PUS }}$ discourse understood communities as a resource for School ${ }^{\text {PLUS }}$ or vice versa.

bell hook's (2000) Feminist Theory: From Margin to Center provides a framework that offers insight into the ways power and dominance might contribute to the edu-centric nature of School $^{\text {PLUS }}$. Her explanation is set within the context of how power operates in relation to race; however, the framework is also a helpful model to understand how the dominance in one sector has the potential to marginalize other sectors. Understood from this perspective, the Education sector produced School ${ }^{\text {PLUS }}$ in ways that inhibited interdependent partnerships with other sectors. hook's model describes how the group with power, influence, and control is positioned in the center, while the group/s with less power remain on the margins.

In the case of School ${ }^{\text {PLUS }}$, the Ministry of Education and schools were at the helm of the change movement. Schools not only held the balance of power and influence, but also their population also outnumbered almost any other profession that fancied a partnership with them. Consequently, the norms and discourses of schools prevailed, sometimes in the most subtle ways, but often marginalizing other professionals in blatant ways. A senior health official noted:

It is difficult to partner with Education when they are such dominant leaders. School $^{\text {PLUS }}$ and integrated services is driven by [the Ministry of Education] Saskatchewan Learning. In my humble opinion, if you want a different education system you need different people making policy. SK Learning is full of very good people but they are all teachers and they all think like teachers. If you want an interdisciplinary perspective you have to have other sectors more intimately involved. Why isn't the School ${ }^{\text {PLUS }}$ unit intersectoral? (as cited by Salm, 2008, p. 128 )

hooks (2000) also suggests that often it is difficult for the center to see beyond its own worldview and the center expects the margins to conform to the norms of the dominant group. 
This configuration reinforces the dominant group's power and maintains the status quo. Although there were specific attempts to engage other sectors, such as in the Caring Across Professions Conference, typically the Education sector invited the participation of others to joinin rather than co-construct integrated service partnerships. Also, when partnerships faltered or failed, the blame was pointed at other ministries or sectors for not being active partners.

Although it might seem natural for schools to be the hubs for service provision for children and youth, it is edu-centric to conceive of students in isolation from their families and

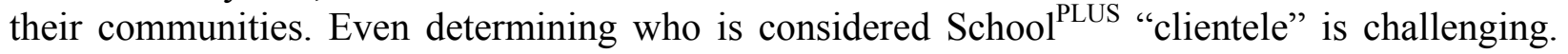
The Education sector generally regards students as their only target audience or "clients." Yet, students are always positioned in wider circles of care within their families and communities. In other words, the scope of practice for other service providers, such as social workers, is much wider than it is for teachers. This difference in scope of practice, positions students in schools in the center, but schools are not necessarily the focus for other human service providers. hooks (2000) suggests that it is the responsibility of the center to move out towards the margin, rather than the reverse. She argues that the margins cannot readjust to the center because if the margins get too close, the center will sanction them out and retake their power. In other words, it is important for the Education sector to fully understand and participate equitably with other sectors before interdependent partnerships can be established. Without genuine interdependence, it is unlikely that cultural and systemic changes can occur. Perhaps, the School ${ }^{\text {PLUS }}$ journey might create a pause for reflection, where the Education sector might enter the human service arena in a more equitable manner. Evidence of this notion is discussed in the final section.

\section{Lack of Collaborative Competencies}

The Canadian Interprofessional Health Collaborative (CIHC, 2010) has identified eight competencies, including collaborative leadership, conflict resolution, team functioning, role clarification, effective communication, and family/student centered care, that promote effective interprofessional working relationships. Clearly, the kind of integrated services inherent in the School $^{\text {PLUS }}$ model demanded a high level of collaborative competencies; yet, most professionals have had little preservice or in-service training to develop competencies in these areas (Barr, Koppel, Reeves, Hammick, \& Freeth, 2005). The CICH framework suggests that the ability of professionals to collaborate is developmental - each of the six competencies develops over an individual's lifespan and often requires a shift in how learners conceptualize collaboration.

Not all Faculties of Education provide courses specifically designed for preservice teachers to construct their professional identity in relation to other human service providers. At the University of Regina, an elective course offers an intensive opportunity for students to explore and develop interprofessional collaborative competencies alongside other students from various human service faculties, but not all students opt for this elective. In order for all students to have exposure to all of the competencies, $50 \%$ of a required pedagogy course focuses on collaboration and the various competencies needed to succeed in an interprofessional context. It is a commendable beginning.

Even though the call for preservice interprofessional education is robust (Barr et al., 2005) a conundrum related to responsibility emerges. In advocating and ensuring interprofessional competency development occurs, the belief that the sole responsibility for the success of school-linked services lies in the hands of the front-line professionals may be 
perpetuated. When partnerships are presented as empowering, uncontested collaborations between professionals, the "pretty story of joined up working" can be presented as nothing less than utopian (Watson, 2012, p. 154). The reverse can be true as well. When challenges occur and, for example, School ${ }^{\text {PLUS }}$ appears dormant, the blame is directed to professionals who simply could not play together nicely in the proverbial sandbox. Watson (2012) emphasizes that this kind of hegemonic discourse must be disrupted to ensure that attention is drawn towards systems and structures, rather than professional deficits. Ostensibly, changing structures and systems is not a speedy process. Expanding opportunities for professional development to hone collaborative competencies offers one avenue to support change, but to avoid downloading the problem to frontline workers, it must be in concert with broader structural changes.

Furthermore, policies that are instrumental in promoting significant cultural change, and that require new skills and competencies, require adequate time to percolate and the implementation ought to take time. Eccles (2012), states that "the need for flexibility, speed of change in patterns of delivery and attitudinal shifts in organizations with long-standing, discrete working culture is challenging. In this respect the implementation of partnership working [is often] flawed through overly ambitious timetables" (p. 30). Rushing the collaboration agenda was evident when an article in the Bulletin announced the demise of School ${ }^{\text {PLUS }}$ after only four years of implementation. Given that 96 recommendations were made in the report and changes required at all levels of engagement, four years seems hardly enough time to make a cultural change.

\section{The Complexity Factor at the Macro Level}

While the term School ${ }^{\text {PLUS }}$ is familiar "lingo" in our province, a common definition and understanding has not become mainstream beyond our borders, or even within them for that matter. Salm (2008) reports that the definition of School ${ }^{\text {PLUS }}$ falls into at least four categories, as professionals constructed their own meaning to this elusive policy term. At one end of the spectrum, some educators perceived that any interaction with another profession is tantamount to School $^{\text {PLUS }}$ collaboration. At the other end of the spectrum, the term School ${ }^{\text {PLUS }}$ is reserved for a more substantial interdependence and a paradigm shift between two or more sectors. Contrasting the two ends of the spectrum demonstrates the extreme variance between expected levels of complexity and interdependence associated with School ${ }^{\text {PLUS }}$. That is not to suggest that School $^{\text {PLUS }}$ ought to be narrowly defined; rather, there is a need for extensive and complex policy interventions at front line, middle management, and government levels. The data from the Bulletin suggests that School $^{\text {PLUS }}$ mainly resided at the micro and meso levels. Actualizing School $^{\text {PLUS }}$ at the government level appeared too complex or perhaps too daunting. Raffo et al. (2009) suggest that policy-makers must engage with the "complexity of knowledge claims where strategising takes account of scope, coherence and power" (p. 351). All three of these factors proved to be problematic for the School ${ }^{\text {PLUS }}$ agenda.

In terms of scope, the range of interventions that were captured under the School ${ }^{\text {PLUS }}$ umbrella provided a narrow scope of intervention, most change occurred at the school level. The STF's consistent scrutiny of the governments' intentions and commitment to School ${ }^{\text {PLUS }}$, may have quelled policy-makers attempts to turn School ${ }^{\text {PLUS }}$ into a handy "silver bullet." Overtime, it proved much more difficult for policy-makers to negotiate fundamental and political changes within their own respective ministries and to realize a more widespread School ${ }^{\text {PLUS }}$ vision. 
Additionally, Raffo et al. (2009) suggest that policy-makers ought to make policy interventions coherent and avoid a "scattergun" approach; that is, igniting a bunch of small-scale initiatives and expecting that somehow they will make a difference. The wide-ranging definitions and descriptions of School ${ }^{\text {PLUS }}$ did not contribute to coherence. Even within one issue of the Bulletin, there is evidence of educators describing prospering School ${ }^{\text {PLUS }}$ initiatives and with a turn of the newspaper page another article announcing its demise. Many small "scattergun" initiatives also complicated measuring tangible outcomes. Due to the complexity and indeterminacy of collaboration, measuring the outcomes has been the "Achilles' heel" of integrated services in most jurisdictions (Dyson \& Todd, 2010). The enthusiasm for the concept and processes of School ${ }^{\mathrm{PLUS}}$ were not met with an equally fit enthusiasm for evaluation or research. If research did occur, it was local, and widespread collective knowledge was not generated in the way it might have been. Lack of evaluation was an oversight that might have been prevented. Despite the challenges often associated with collaborative working, Cummings, Dyson, and Todd (2011) suggest evaluation processes and a range of methodologies that they used to evaluate Full Services Extended Schools in the United Kingdom. Seemingly, there are ways forward in this regard.

Finally, issues of power must be addressed in relation to how policy-makers strategize with complex knowledge. There was an original plan to ensure all the human service ministries contributed to School ${ }^{\text {PLUS }}$ in an equitable way but there was a power differential, both horizontally across the sectors and vertically within the sectors. The senior discussion forums, for example, held promise for a fully integrated approach to interagency service and a shared plan of action but even in the collectively written agreement the emphasis in the nine key priorities for action related to school reform, not systemic reform (Ministry of Education, 2002). Lawson (2013) states that system reform is possible, describing those partnerships that create systemic change and public policy intervention as third generation partnerships. Even though School $^{\text {PLUS }}$ was originally described as a new institutional design, it did not result in widespread structural changes. Lawson's third generation idea, however, provides hope for eventual systemic reform. In the case of School ${ }^{\text {PLUS }}$, disrupting the status quo may have been more difficult than anyone anticipated.

Raffo, et al. (2009) state that for "policy makers [who] are implicated in these inequalities, particular forms of courage are required for them to step outside the social arrangements which have placed them in a privileged position in the first place" (p. 352). One could argue that the original task force that engaged in public dialogue and constructed the Role of the Schools report opened up the space for redistribution of power and provided voice and more local control over integrated services. Somewhere along the journey, however, at the macro level, School ${ }^{\text {PLUS }}$ did not lend itself to a redistribution of power amongst other ministries. As a result, the Ministry of Education bore the primary responsibility for School ${ }^{\text {PLUS }}$ and maintained central control. Although it might appear School ${ }^{\text {PLUS }}$ has met its demise, there is currently a new energy around interprofessional collaboration in the province and the beat of School ${ }^{\text {PLUS }}$ seems to play on.

\section{The Policy Practice Paradox}

For a policy that is seemingly inactive and no longer current in government documents or on the website - the sentiments underpinning School ${ }^{\text {PLUS }}$ have never been so alive. Perhaps this paradox can be explained because the idea of School ${ }^{\text {PLUS }}$ emerged from widespread public consultation 
that was conducted throughout the province. It would be fair to say, therefore, that educators and their human service counterparts have been engaged in School ${ }^{\text {PLUS }}$-like activities and imagining potential possibilities for better collaborative practice prior to the Role of the Schools Report in 2001. After School ${ }^{\text {PLUS }}$ was coined and described in the official report, a more coherent and specific vision was available for all of the stakeholders to share. School ${ }^{\text {PLUS }}$ policy may have not endured, but the concept of collaboration between sectors is deeply rooted in a dynamic grassroots practice. That is not to suggest that School ${ }^{\text {PLUS }}$-related policy has not been useful in the past, nor that future policy development would not benefit school-linked service practice. However, it is clear that the development and sustainability of school-linked or interprofessional practice does not solely depend on widespread, provincial policy.

One example of how the School ${ }^{\text {PLUS }}$ philosophy lives on is in an intersectoral model developed in north-central Saskatchewan. This collaborative effort demonstrates how schools are changing practices to be part of unique intersectoral practices. While government funding made the model operational, the school division participated in the creation of an interagency approach that de-centers schools as the center of service and embeds services in a wider network of school and other services. It is not a crisis intervention strategy. Rather, this model offers a regularly scheduled and structured discussion amongst service providers to prevent problems and mitigate risk by offering support to individuals and families. It is not edu-centric; collaborative competencies are being developed and government support has been sustained thus far. These and other interagency collaborations continue to flourish in the same grassroots locations that provided the catalyst for the Role of the Schools Report in the first place. The School ${ }^{\text {PLUS }}$ philosophy is not only deeply embedded in the vernacular of educators but also it is also part of their vision to create an improved, integrated system that provides better outcomes for children and youth. As policy-makers look to the future to plan school-linked service possibilities, it is important to pay heed to the edu-centric nature of the Education sector, to provide professional development for building collaborative competencies, and to account for scope, coherence, and power when strategizing. Perhaps, the intensive journey that was coined School ${ }^{\text {PLUS }}$ will provide the required foundation on which third generation partnerships (Lawson, 2013) will genuinely emerge and become sustainable. 


\section{References}

Ainscow, M., Dyson, A., Goldrick, S., \& West, M. (2012). Making schools effecting for all: Rethinking the task. School Leadership and Management: Formerly School Organisation, 32(3), 197-213.

Anderson-Butcher, D., Lawson, H., Iachini, A., Bean, G., Flaspohler, P., \& Zullig, K. (2010). Capacity-related innovations resulting from the implementation of a community collaboration model for school improvement. Journal of Educational \& Psychological Consultation, 20(4), 257-287.

Anning, A., Cottrell, D., Frost, N., Green, J., \& Robinson, M. (2010). Developing multiprofessional teamwork for integrated children's services. Berkshire, England: Open University Press.

Barr, H., Koppel, I., Reeves, S., Hammick, M., \& Freeth, D. (2005). Effective interprofessional education: Argument, assumption and evidence. Oxford, England: Blackwell Publishing.

Carr-Stewart, S. (2003). School ${ }^{\text {PLUS }}$ and changing demographics in Saskatchewan: Towards diversity and educational communities. Canadian Journal of Native Education, 27(2), 223-234.

CIHC (2010). Canadian Interprofessional Health Collaborative: A national competency framework. Retrieved from http://www.cihc.ca/files/CIHC IPCompetencies_Feb1210.pdf

Crane, P., \& Livock, C. (2012). Joined-up practice: Five areas of exemplary practice for social workers and educators to re-engage homeless youth. Youth Studies Australia, 31(2), 4452.

Cummings, C., Dyson, A., \& Todd, L. (2007). Toward extended schools? How education and other professionals understand community-oriented schools. Children and Society, 21(3), 189-200.

Cummings, C., Dyson, A., \& Todd, L. (2011). Beyond the school gates: Can full service and extended schools overcome disadvantage? New York, NY: Routledge.

D'Angelo, A., Rich, L., \& Kwiatt, J. (2013). Integrating family support services into schools: Lessons from the Elev8 initiative. (Chapin Hall Issue Brief.) Chapin Hall at the University of Chicago. Retrieved from http://www.chapinhall.org/sites/default/files/publications/01_22_13_Integrating\%20Fa mily\%20Support_IB.pdf

Dryfoos, J. (1994). Full-service schools. San Francisco, CA: Jossey Bass.

Dryfoos, J., \& Maguire, S. (2002). Inside full-service community schools. Thousand Oaks, CA: Corwin Press.

Dyson, A. (2011). Full service and extended schools, disadvantage and social justice. Cambridge Journal of Education, 41(2), 177-193. 
Dyson, A., \& Todd, L. (2010). Dealing with complexity: Theory of change evaluation and the full service extended schools initiative. International Journal of Research and Method in Education, 33(2), 119-134.

Eccles, A. (2012). Partnerships: the politics of agendas and policy implementation. In J. Forbes \& C. Watson (Eds.), The transformation of children's services: Examining and debating the complexities of professional working. New York, NY: Routledge.

Edwards, A., Daniels, H., Gallagher, T., Leadbetter, J., \& Warmington, P. (2009). Improving inter-professional collaborations: Multi-agency working for children's well being. Oxford, England: Routledge.

Forbes, J., \& Watson, C. (2012). Inter/professional children's services: Complexities, transformation and future. In J. Forbes and C. Watson (Eds.), The transformation of children's services. Examining and debating the complexities of inter/professional working, (pp. 183-194). London, UK: Routledge.

Furrer, C., Magnuson, L., \& Suggs, J. (2012). Getting them there, keeping them there: Benefits of an extended school day program for high school students. Journal of Education for Students at Risk, 17(3), 149-164.

hooks, b. (2000). Feminist theory: From margin to center. Cambridge, MA: South End Press.

HM Treasury. (2003). Every child matters. London, UK: HMSO. Retrieved from: http://webarchive.nationalarchives.gov.uk/20130401151715/http://www.educatio n.gov.uk/publications/eOrderingDownload/CM5860.pdf

Hulme, R., Cracknell, D., \& Owens, A. (2009). Learning in third spaces: Developing transprofessional understanding through a practitioner enquiry. Educational Action Research, 17(4), 537-550.

James, P., \& St. Leger, P. (2003). Crossing school-community boundaries for vocational education: Enabling learning for potential early school leavers. International Journal of Training and Research, 1(1), 1-22.

Lawson, H. (2003). Pursuing and securing collaboration to improve results. In M. Brabeck, M. Walsh, \& R. Latta (Eds.), The contribution of interprofessional collaboration and comprehensive services to teaching and learning (pp.9-46). Chicago, IL: University of Chicago Press.

Lawson, H. (2004). The logic of collaboration in education and the human services. Journal of Interprofessional Care, 18(3), 225-237.

Lawson, H. (2013). Third-generation partnerships for P-16 pipelines and cradle-through-career education systems. Peabody Journal of Education, 88(5), 637-656.

Miller, F., \& Alvardo, K. (2005). Incorporating documents into qualitative nursing research. Journal of Nursing Scholarship, 37 (4), 348-353.

Ministry of Education, Government of Saskatchewan. (2002). Securing Saskatchewan's future.

Ministry of Education, Government of Saskatchewan. (2003, Spring). School ${ }^{\text {PLUS }}$ at a glance. 
Ministry of Education, Government of Saskatchewan. (2004, Winter). School ${ }^{\text {PLUS }}$ is happenin'. School ${ }^{\text {PLUS }}$ progress.

Ministry of Education, Government of Saskatchewan. (2004), Destination School ${ }^{\text {PLUS }}$ : A leadership guide for School ${ }^{\text {PLUS }}$ environments.

Nielsen, J. (2006, April 26). Future of School ${ }^{\text {PLUS }}$ seems uncertain after latest budget. The Bulletin, 72(8), 1.

Nielsen, J. (2006, Nov. 22). Teachers are the plus. The Bulletin, 73(3), 1.

Nielsen, J. (2007, June 13). Young insists School ${ }^{\text {PLUS }}$ remains alive. The Bulletin, 73(10), 1.

Nielsen, J. (2008, June 11). Pediatric services provide healthy addition to community school. The Bulletin, 74(10), 3.

Nielsen, J. (2008, Dec. 17). Krawetz envisions School ${ }^{\text {PLUS }}$ as part of overall capital funding. The Bulletin, 75(4), 2.

Nielsen, J. (2009, Feb. 18). Rekindled interest in School ${ }^{\text {PLUS }}$ leaves educators hopeful. The Bulletin, 75(6), 1.

Nielsen, J. (2009, April 15). Education property tax shift represents funding change. The Bulletin, 75(8), 2.

Nielsen, J. (2009, June 17). Panelists agree that School ${ }^{\text {PLUS }}$ vision must not be forgotten. The Bulletin, 75(10), 1.

Nielsen, J. (2010, Jan. 20a). Student assessment can be complex. The Bulletin, 76(5), 4.

Nielsen, J. (2010, Jan. 20b). Success of judo-based program eclipses all expectations. The Bulletin, 76(5), 6.

Nielsen, J. (2010, June 16a). Panel on School ${ }^{\text {PLUS }}$ achievement report sure to have major impact. The Bulletin, 73(6), 3.

Nielsen, J. (2010, June 16b). Boyczuk outlines school council role. The Bulletin, 73(6), 4.

Nielsen, J. (2010, November 10). Neudolf says teacher have key role in fighting health disparities. The Bulletin, 77(3), 3.

Nielsen, J. (2011, January 19). Team approach big plus for Prairie South division. The Bulletin, $77(5), 5$.

Nielsen, J. (2011, April 11). Allen says education funding blueprint antiquated. The Bulletin, $77(8), 2$.

Nielsen, J. (2011, June 15). Allen contemplates challenge. The Bulletin, 77(10), 1.

Nielsen, J. (2012, February 15). Education always at heart of Rothwell's career journey. The Bulletin, 78(6), 3.

Nielsen, J. (2012, October 17). Marchuk shares education experience with STF delegation. The Bulletin, 79(2), 3. 
Nielsen, J. (2012, November 14). Politician hear teachers' concerns at councillor conference. The Bulletin, 79(3) 2.

Nielsen, J. (2012, December 12). Neudolf makes economic case for early childhood funding. The Bulletin, 79(4), 3.

Nielsen, J. (2013, February 13). St. Mary facility reinventions places it at vanguard of new education model. The Bulletin, 79(6), 3.

Nielsen, J. (2013, June 12). Wall hears consistent message from teachers during visits. The Bulletin, 79(10), 1.

Nielsen, J. (2014, January 14). Florizone share thoughts on education sector plan. The Bulletin, $80(5), 3$.

Patton, M. (2002). Qualitative research and evaluation methods. Thousand Oaks, CA: Sage Publication.

Pillay, M. (2007, January 24). School ${ }^{\text {PLUS }}$ requires commitment. The Bulletin, 73(5), 4.

Province of Manitoba. (2014). Manitoba community schools partnership initiative supporting families, strengthening communities, helping students succeed. Retrieved from http:/www.edu.gov.mb.ca/cspi/documents/index.html

Province of Nova Scotia. (2014). SchoolsPlus. Retrieved from https://schoolsplus.ednet.ns.ca/

Raffo, C., Dyson, A., Gunter, H., Hall, D., Jones, L., \& Kalambouka, A. (2009). Education and poverty: Mapping the terrain and making the links to educational policy. International Journal of Inclusive Education, 13(4), 341-358.

Regnier, R. (2012). SchoolPLUS: Creating community schools through integral development. in education, 18(1), 67-78. Retrieved from http://ineducation.ca/ineducation/article/view/26/335

Salm, T. (2008). The challenge and possibilities of interprofessional collaboration for social justice. New York, NY: Edwin Mellen Press.

STF. (2014).About the Saskatchewan Bulletin. Saskatchewan Bulletin. Retrieved from https://www.stf.sk.ca/portal.jsp?Sy3uQUnbK9L2RmSZs02CjVy0w7ZkI/ks6g2u00gzAt sk=F\#https://www.stf.sk.ca/portal.jsp?Sy3uQUnbK9L2RmSZs02CjV/Lfyjbyjsxs6m0v $\mathrm{V} 2 \times 2 \mathrm{Y} 7 \mathrm{Q}=\mathrm{F}$

Tymchak, M., Task Force, and Public Dialogue on the Role of the School. (2001). SchoolPlus: A vision for children and youth. Toward a new school, community and human service partnership in Saskatchewan. Final report to the Minister of Education, Government of Saskatchewan.

Tyack, D. (1992). Health and social services in public schools: historical perspectives. In The Future of children: school-linked services. Los Altos, CA: The Center for the Future of Children. 
Watson, C. (2012). The pretty story of 'joined up working' questioning interagency partnerships. In J. Forbes and C. Watson (Eds.), The transformation of children's services. Examining and debating the complexities of inter/professional working (pp. 154-168). London, UK: Routledge

White, G., Thomas, J., Weldon, P., Lawrence, A., Galatis, H., Tyndall, J. (2013). Grey literature in Australian education. Grey Journal, 9(2), 103-108. 